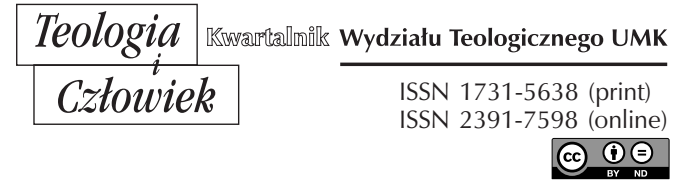

43(2018)3, ss. $65-80$

KS. WIKTOR OSTROWSKI

\title{
DYNAMIZM WIARY CHRYSTOLOGICZNEJ W UJĘCIU JEANA GALOT
}

DOI: http://dx.doi.org/10.12775/TiCz.2018.027

Streszczenie. W artykule mowa jest o dynamizmie wiary, jaką objawia chrystologia sięgająca źródeł, czyli ukazująca ziemskie życie Jezusa Chrystusa. Każde rozważania o Chrystusie zawsze muszą być oparte na doświadczeniu wiary w historycznego Jezusa i zakotwiczone w dialogalnym rodowodzie pierwotnej chrystologii. Według Jeana Galot kierunek poszukiwania odpowiedzi na pytanie o podstawę chrystologii w jej dynamizmie trzeba dostrzec w kontekście sceny i słów samego Pana Jezusa zwróconych do uczniów: „Za kogo mnie uważacie?” (Mt 16,15). Chrystologia pierwotna ma zatem rodowód dialogalny. Sam bowiem Chrystus chciał umieścić chrystologię w dynamizmie dialogu. Pragnął On, aby nauka ta, była dialogiem, i aby jej twierdzenia były wynikiem poszukiwania oraz opisywania istoty wydarzeń, które znajdują się w ewangeliach. Na ten zamysł Chrystusa wskazuje fragment Jego rozmowy z Apostołami pod Cezareą Filipową (por. Mt 16,13-20), ten mianowicie, w którym Ewangeliści przedstawiają zapytanie Mistrza i odpowiedź Piotrową na nie. Wypowiedziane tam słowa są dla J. Galot punktem wyjścia w ukazaniu kierunków rozważań chrystologicznych.

Słowa kluczowe: chrystologia; dialog; wyznanie Piotra.

Abstract. Dynamism of Christological faith in terms of Jean Galot. The article is about the faith's dynamism revealed in Christology based on the sources which is showing the earthly life of Jesus Christ. All considerations about Christ always must be 
based on the experience of faith in the historical Jesus and anchored in the dialogical origin of primordial Christology. According to Jean Galot, the search for the answer to the question about the basis of Christology in its dynamism must be seen in the context of the scene and words of the Lord Jesus addressed to the disciples: "Who do you think I am?" (Mt 16,15). Therefore the primal Christology has a dialogical origin. Christ himself wanted to place Christology in the dynamism of dialogue. He wished that this scene would become a dialogue and that its claims would be the result of searching and describing the essence of events that are found in gospels. A part of his conversation with the Apostles near Caesarea Philippi (Mt 16,13-20) is found to be a proof to the above. In that dialogue Evangelists present the Master's question and the Peter's answer. Those words are the starting point of J. Galot's considerations and show the directions of his Christological reflections.

Keywords: christology; dialogue; Peter's profession of faith.

\section{WSTĘP}

Wierzymy i wyznajemy, że Jezus z Nazaretu, urodzony jako Żyd z córki Izraela w Betlejem, w czasach króla Heroda Wielkiego i cezara Augusta I, z zawodu cieśla, który umarł ukrzyżowany w Jerozolimie za czasów namiestnika Poncjusza Piłata, w czasie rządów cezara Tyberiusza, jest odwiecznym Synem Bożym, który stał się człowiekiem. Wierzymy, że „od Boga wyszedł” (J 13,3), „z nieba zstąpił” (J 13,3; 6,33), „przyszedł w ciele” (1 J 4,2), ponieważ „Słowo stało się ciałem i zamieszkało wśród nas" $(\mathrm{J} 1,14)^{1}$.

Ze względu na to stałe „zamieszkanie wśród nas”, narodzin Jezusa w Betlejem nie można uznać za zamkniętą przeszłość. Przed Nim bowiem staje cała ludzka historia: Jego obecność oświeca zarówno naszą teraźniejszość, jak i przyszłość ${ }^{2}$. Odkąd więc Bóg całkowicie wypowiedział się w Jezusie, Wcielonym Słowie, człowiek nieustannie szuka na ziemi prawdziwego Boga w Chrystusie. Jezus Chrystus staje się dla nas „miejscem doświadczenia Boga"3. Staje się On potężnym motorem pobudzającym myśl ludzką wobec niezwykłego odczucia Jego tajemnicy i zarazem chę-

1 Katechizm Kościoła Katolickiego, Poznań 1994, n. 423.

2 Por. Jan Paweł II, bulla „Incarnationis mysterium”, Poznań 1998, n. 1.

${ }^{3}$ Jezus - Ort der Erfahrung Gottes, Freiburg 1976; cyt. za: A. Nossol, Teologia bliższa życiu. Wpływ teologii na egzystencję chrześcijańska, Opole 1984, s. 31. 
ci jej poznania. Apostołowie po uciszeniu przez Jezusa burzy na morzu „zlękli się bardzo i mówili jeden do drugiego: «Kim właściwie On jest, że nawet wicher i jezioro są Mu posłuszne?»” (J 4,41). Takie same pytania pojawiają się od tego momentu w historii ludzkości aż po obecne czasy ${ }^{4}$. Odpowiedzi na pytanie o wiarygodną odpowiedź o Jezusie Chrystusie udzielił Jean Galot SJ swą oryginalną koncepcją dialogalnego dynamizmu chrystologii. Celem niniejszego artykułu będzie ukazanie tych poglądów J. Galot w szerokim kontekście współczesnej myśli chrystologicznej.

\section{OSOBA JEZUSA CHRYSTUSA W CHRYSTOLOGII}

Chrystologia jest ze swej natury dynamiczna. Przedmiotem bowiem jej zainteresowania jest Jezus Chrystus - Jego wcielenie oraz wzajemna relacja w Nim natury boskiej i ludzkiej, czyli unia hipostatyczna ${ }^{5}$. Podstawą tego dynamizmu w chrystologii jest „zbawcze misterium Słowa, które stało się Ciałem”'. Dynamizm chrystologii zawarty jest w słowie: „stawać się" występującym w Ewangelii św. Jana 1,14. Zwrot ten stanowi biblijne potwierdzenie tego dynamizmu, gdyż suponuje on pewną „zmienność Boga”, który przez wcielenie wszedł w stosunki realne ze światem, oddając temu światu swą miłość, współczucie i poświęcając się dla niego ${ }^{7}$. Dynamizm chrystologii wynika nie tylko z powiązania jej z traktatem o Wcieleniu Słowa, lecz także - z traktatem o odkupieniu człowieka. Jean Galot, jako przedstawiciel nowszej wizji w ujęciu chrystologii ${ }^{8}$, próbuje

4 Por. W. Granat, Dogmatyka katolicka, Lublin 1959, t. 3, s. 7.

${ }^{5}$ Por. J. Galot, Chi sei Tu, o Cristo, Firenze 1977, s. 9; także: Wielka Encyklopedia Powszechna PWN, Warszawa 1965, t. 2, s. 511; Z. Poniatowski, Chrystologia - kierunki, problemy, aporie, „Literatura na świecie” 12 (1974), s. 95n.

6 Por. A. Nossol, Per Christum, s. 25.

7 Por. „Egli [Jean Galot - W.O.] afferma la necessita di una cristologia dinamica che, aderendo maggiormente ai dati biblici, prenda sul serio il »divenire» di Dio. [...] La «mutabilitá» di Dio emerge dallincarnazione del Verbo. L' incarnazione lascia infatti intravvedere che Dio e entrato in un «rapporto reale» col mondo, in cui ha impegnato se stesso in modo libero e sovrano, in un rapporto reale di amore verso luomo che lo porta sacrificarsi per lui, a compatire." B. Mondin, Le cristologie moderne, Alba 1976, s. 26n.

${ }^{8}$ Inni przedstawiciele: K. Rahner, Ch. Duquoc. 
wyjaśnić ów dynamizm, zwracając uwagę na analizę Wcielenia Syna Bożego i Jego całego życia ziemskiego.

Według Jeana Galota, kierunek poszukiwania odpowiedzi na pytanie o podstawę chrystologii w jej dynamizmie trzeba dostrzec w kontekście sceny i słów samego Pana Jezusa zwróconych do uczniów: „Za kogo mnie uważacie?" Nie zadaje On pytania w formie: Jakie dzieło zostało mi zlecone? Doskonale jednak swym życiem i przepowiadaniem wykazał, jakie jest to dzieło i na czym polega Jego misja ${ }^{10}$. To pytanie w ustach Jezusa staje się początkiem chrystologii dynamicznej i chrystologii dialogu według Jeana Galota. Szczególnie istotnym jawi się dla niego problem, aby podjąć refleksję nad całokształtem życia Jezusa. Wszakże Zbawiciel jest Człowiekiem zrodzonym z Niewiasty, który żył w konkretnej historii. Poddany był ograniczeniom, które nakładał ówczesny świat i ówczesne warunki, aż do swej śmierci. W związku z tym człowieczeństwo nie jest w Chrystusie jakimś dodatkiem, lecz konsekwencją zjawienia się Boga w świecie. Nie jest też tworem abstrakcyjnym, ale człowieczeństwem jako takim. W misterium Wcielenia stało się ono pełną rzeczywistością Słowa i wraz ze swoim życiem w tajemniczy sposób „dotknęło” istnienia Boga, w taki sposób, że rzeczywistość Boża zajęła miejsce rzeczywistości ludzkiej i odwrotnie ${ }^{11}$.

Jezus mógłby zadać powyższe pytanie o swoją misję w celu stwierdzenia, czy dobrze uczniowie zrozumieli sens jego dzieła. Faktycznie jednak Nauczyciel ograniczył się do pytania podejmującego problem Jego natury ${ }^{12}$. Z własnego doświadczenia wiemy, że pytając kogoś „Kim jesteś? Kto ty jesteś?”, chcemy jednocześnie zdobyć odpowiedź na problem: „Co cię odróżnia od innych?”. Zatem kwestie: „Kto jest? Kim jest?” - są odzwierciedleniem naszego „ja” i relacji naszej do innych. Kieruje też naszą uwagę na osobę, a nie na przedmiot ${ }^{13}$. Jezus, zadając to problemowe pytanie swym uczniom, chce, aby ci, z którymi przebywa, wypowiedzieli swoją opinię o Nim, aby przez to On sam mógł zbadać trafność ich oceny

\footnotetext{
9 Por. Mt 16,15; Mk 8,29; Łk 9,20.

10 Por. J. Galot, Chi sei Tu, s. 43-47.

${ }^{11}{ }^{1}$ Por. J. Królikowski, Mysteria vitae Christi, s. 28 n.

12 Por. tamże, s. 48-51.

13 Por. tamże, s. 267-269.
} 
Jego osoby ${ }^{14}$. Zwrotem: „Za kogo mnie uważacie?” Jezus trafił Apostołom prosto w serca. Przecież od pierwszego spotkania z Nim zadawali sobie pytanie „Kim jest Jezus?” i do tej pory nie znajdowali na nie odpowiedzi. O tym, że jest On Mesjaszem, nie byli zawsze przekonani ze względu na Jego dziwne zachowanie - przywracał zdrowie chorym, ale zabraniał o tym mówić; czynił wiele dobrego, lecz przekraczał często przepisy o szabacie i rytualnej czystości ${ }^{15}$. Pytaniem tym stara się Jezus uzyskać odpowiedź od tych, którzy w Niego wierzą i są Mu oddani. Prosi ich o wyjaśnienie kwestii, dlaczego Mu zawierzyli. I jednocześnie zaświadcza, że wiara każdego, także bliskich Mu uczniów, musi opierać się na przyjęciu Jego osoby ${ }^{16}$. Wszakże Chrystus, jako Nauczyciel, nie narzuca się swym uczniom, lecz rozwija w nich zmysł nadprzyrodzoności, aby oni sami mogli dostrzec prawdę i dojść o własnych siłach, wspierani łaską, do rozwiązania zagadnienia, jakie stawia osoba Jezusa ${ }^{17}$. Bardzo ważną kwestią w rozwiązaniu problemu wiary w Chrystusa jest dogłębna analiza dzieł przez Niego dokonywanych. Ten wręcz żąda, by spojrzenie uczniów nie ograniczyło się tylko do widzenia Jego czynów, ale nawet nie można prawdziwie zrozumieć dokonań Jezusa bez poznania Jego osoby ${ }^{18}$.

Zanim Jezus skieruje pytanie bezpośrednio w stronę uczniów, prosi ich najpierw o odpowiedź w kwestii: „Za kogo uważają mnie ludzie?”19 Opinie ludzkie referowane przez uczniów wskazują, że postawiony problem dotyczy tożsamości Jezusa ${ }^{20}$. Odpowiedzi, jakich udzielają uczniowie, są tylko okazją do głębszej refleksji nad sformułowaniem ich własnego zdania na ten temat. Stanowią one element, który pobudza do odczucia niezadowolenia tą czy inną odpowiedzią na postawione pytanie ${ }^{21}$. Ludzie starali się utożsamić Jezusa z jakąś znaną osobistością. Dla nich był On mężem Bożym, przez którego Bóg dokonuje zbawczych dzieł. Opinie te

\footnotetext{
14 Por. tamże, s. 9, 51-52.

15 Por. F. Gryglewicz, Za kogo mnie uważacie? Chrystus w oczach swoich wspót-
} czesnych, Poznań-Warszawa-Lublin 1966, s. 112.

${ }_{16}$ Por. J. Galot, Chi sei Tu, s. 9, 53-54.

17 Por. tenże, Serce Ojca, [tł. S. M. G.], Warszawa 1962, s. 258.

18 Por. tenże, Chi sei Tu, s. 54-57.

19 Por. Mk 8,27; Mt 16,13; Łk 9,18.

20 Por. J. Galot, Chi sei Tu, s. 11-13, 60.

${ }^{21}$ Por. E. Szymanek, Za kogo mnie, s. 232. 
różniły się między sobą w stwierdzeniach, czy jest On zmartwychwstałym Janem Chrzcicielem ${ }^{22}$, czy Eliaszem, który miał się ponownie zjawić jako zwiastun czasów mesjańskich ${ }^{23}$, czy wreszcie jakimś innym prorokiem ${ }^{24}$. Jezus nie przypisywał tym opiniom większego znaczenia, nawet się nimi nie zajął, ponieważ nikt z ludu nie patrzył na Niego jako na tego, w którym spełniają się obietnice mesjańskie ${ }^{25}$.

Pytanie powyższe wskazuje wyraźnie, że problem, który ludzie tamtych czasów starali się rozwikłać, był i jest nadal istotny. Aby więc zrozumieć dzieło Jezusa, trzeba poznać Jego osobę. Ze względu także na to, iż wiara chrześcijańska polega na przyjęciu całego Chrystusa, a nie tylko Słowa Bożego, i na ufności w wypełnienie się w Nim dzieła zbawczego, u początku rozwoju chrystologii zajęto się wyjaśnianiem ontologii Jezusa, z konieczności koncentrując się na Jego osobie ${ }^{26}$.

Analiza słów i czynów Jezusa to jeden z aspektów, które pomagały uczniom odkryć tajemnicę osoby Mistrza ${ }^{27}$. Coraz jaśniej ukazując im, kim jest, musiał zarazem tak się objawiać, aby uczniowie mogli zrozumieć Jego istotę. Dlatego też całe ziemskie życie Jezusa było powolnym procesem odkrywania im samego siebie. Toteż wiara apostołów wzrastała poprzez poznawanie zarówno tajemnicy Jezusa, jak i doświadczanie w Nim mocy Boga - Królowania Bożego. W tym ludzkim doświadczeniu poznawali oni moc, która zwycięża zło, potęgę, którą niesie przebaczenie, a przede wszystkim, miłość, która jednoczy ${ }^{28}$.

Życie ziemskie Jezusa stanowi dla wiary pewnego rodzaju „podajnik” koniecznych danych, które nie mogą pochodzić tylko z wydarzeń popaschalnych, nadających jej pełną spójność i zarazem będących od-

${ }^{22}$ Por. Mt 14,2; Mk 6,14; Łk 9,7.

${ }^{23}$ Por. Mk 6,15; 8,28; Łk 9,8.19; Mt 16,14; Ml 3,1.23n.

${ }^{24}$ Por. Łk 9,19; Mt 16,14; Mk 8,28.

${ }^{25}$ Por. J. Galot, Chi sei Tu, s. 11, 62-64; także: F. Gryglewicz, Za kogo mnie, s. 111; W. E. May, Chrystus w myśli, s. 9n; R. Bartnicki, Wyznanie Piotra pod Cezarea Filipowa i obietnica prymatu, „Homo Dei” 3 (1980), s. 207; G. Ricciotti, Życie Jezusa Chrystusa, tłum. J. Skowroński, Warszawa 1954, s. 418n.

26 Por. J. Galot, Chi sei Tu, s. 11, 64-65, 205.

${ }^{27}$ Por. tamże, s. 14-16.

${ }^{28}$ Por. J. Kulisz, Bóg w Jezusie, s. 73. 
powiedzią na ewentualne wątpliwości ${ }^{29}$. Jak zauważa trafnie C. Duquoc: „właśnie rzeczywistość historyczna Jezusa z Nazaretu wyznacza sens Zmartwychwstaniu, lecz z kolei Zmartwychwstanie nadaje tej historii wymiar uniwersalny, a zatem zawsze aktualny. Chrystologia włącza się w ten bieg rzeczy: wyznaje $\mathrm{z}$ wiarą Zmartwychwstanie, ale po to, by zwrócić się ku Jezusowi z Nazaretu, bo właśnie na podstawie Jego istnienia ziemskiego majestatyczne nazwy, które przyznała Mu wspólnota chrześcijańska, nabierają treści i konkretnego sensu” ${ }^{30}$. Z tego też względu sensowne wydaje się zdanie J. Galota o tym, że „chrystologia, która chciałaby zajmować się jedynie Chrystusem Zmartwychwstałym, nie odkryłaby pewnych, koniecznych aspektów Jego osoby"31. Chodzi tu w głównej mierze o relacje: Jezus-Ojciec, Jezus-Apostołowie (uczniowie), Jezus-faryzeusze i uczeni w Piśmie itp. Relacje te bez znajomości ziemskiego życia Jezusa trudno poznać, ponieważ wydarzenia popaschalne owych odpowiedzi nie udzielają ${ }^{32}$.

Istotnym na tym etapie naszych dociekań jest fakt, że przy rozważaniach chrystologicznych można postępować dwojako: przechodzić od dzieła Chrystusa, Jego słów i czynów, do samej Jego osoby albo w kierunku - od osoby Chrystusa do Jego dzieła. Innymi słowy, można rozpoczynać rozważania chrystologiczne od ukazania tego, czego Chrystus dokonał, by następnie analizować to, kim był, lub też postępować w odwrotnym kierunku. Pierwszy sposób wydaje się bardziej zgodny z biblijnym i fenomenologicznym charakterem najnowszych ujęć w chrystologii, w tym z ujęciem osoby Jezusa Chrystusa proponowanym przez Jeana Galota $S^{33}$. To wyżej wspomniane ujęcie w chrystologii nie zamierza, jak wydawać by się mogło, sprowadzać Jezusa historycznego do rzędu wszystkich pozostałych ludzi i przeczyć Jego istotnej relacji do Boga. Lecz wręcz przeciwnie: pragnie ono ustrzec postać Jezusa od dalszego spychania na margines współczesnego życia, wypracowując

29 Por. J. Galot, Chi sei Tu, s. 14-16.

${ }^{30}$ Ch. Duquoc, Jezus Chrystus. Zarys chrystologii, tłum. D. Szumska, Warszawa 1976, s. 28.

31 J. Galot, Chi sei Tu, s. 15.

32 Por. tamże, s. 98-99.

${ }_{33}$ Por. W. Łydka, Potrzeba $i$ drogi integracji w chrystologii, „Studia Theologiae Varsoviensia” 15 (1977) 1, s. 73-74. 
przy tym nowe uzasadnienie i wyjaśnienie tego Bożego synostwa. Dlatego też podkreśla specyficzną obecność Boga w Jezusowym człowieczeństwie, umacniając jednocześnie wymiar historyczny i antropologiczny wizji Chrystusa $^{34}$. Przykładem ilustrującym omawiany problem niech będzie sytuacja Cierpiącego Sługi Jahwe z Iz 53,2-11 tak charakterystyczna dla życia ziemskiego Jezusa, właśnie w przeciwieństwie do Jego życia chwalebnego. Scena ta konieczna jest po to, aby lepiej zrozumieć, kim był i jest Jezus dla ludzkości włączonej w życie ziemskie, a tym bardziej dla poszczególnego człowieka ${ }^{35}$.

Zastanówmy się jeszcze nad inną kwestią. Jeśli istota objawienia, czyli to, kim jest Jezus, zostałaby odsłonięta przez Chrystusa Zmartwychwstałego, oznaczałoby to ograniczenie mocy Bożej do objawienia się ludziom nie inaczej, jak tylko w sytuacji doskonalszej od człowieczego życia ziemskiego, przekraczając tym samym prawa świata i materii ${ }^{36}$. Jezus jednak ukazał, że objawienie mogło się doskonale zrealizować przez prawdziwą egzystencję ludzką ${ }^{37}$.

\section{DIALOGALNY RODOWÓD PIERWOTNEJ CHRYSTOLOGIl}

Jak zauważa J. Galot, chrystologia pierwotna, ma rodowód dialogalny. Sam Chrystus chciał umieścić chrystologię w dynamizmie dialogu. Pragnął On, aby nauka ta, była dialogiem, i aby jej twierdzenia były wynikiem poszukiwania oraz opisywania istoty wydarzeń, które znajdują się w ewangeliach ${ }^{38}$. Na ten zamysł Chrystusa wskazuje fragment Jego rozmowy z Apostołami pod Cezareą Filipową ${ }^{39}$, ten mianowicie, w którym Ewangeliści przedstawiają zapytanie Mistrza i Piotrową odpowiedź na nie. Wypowiedziane bowiem słowa podczas tego zdarzenia czyni J. Galot punktem wyjścia swej chrystologii.

\footnotetext{
${ }^{34}$ Por. A. Nossol, U podstaw aktualnych dyskusji, s. 9.

${ }_{35}$ Por. J. Galot, Chi sei Tu, s. 14-16.

36 Por. tamże.

37 Por. tamże.

38 Por. tamże, s. 11-12.

39 Por. Mt 16,13-20; Mk 8,27-30; Łk 9,18-21.
} 
W pytaniu „Za kogo mnie uważacie?” objawia się wola Jezusa oparcia chrystologii na formie pytania i odpowiedzi, z podkreśleniem roli relacji interpersonalnych. Owo pytanie bowiem wzywa uczniów do wyrażenia własnego ich zdania o Mistrzu ${ }^{40}$. Pytanie takie nie przynależy do powszechnych dialogów między ludźmi, dlatego też należy przypuszczać, że pod tym powyższym pytaniem kryje się głęboka tajemnica ${ }^{41}$. Nie jest to pytanie, które zadaje się w sytuacji ratowania własnej dumy pytającego, gdy chce się zakończyć spór słowny pozornym tylko, ale satysfakcjonującym pytającego, zwycięstwem nad pytanym. Takie rozumienie pytania „Za kogo mnie uważacie?” jest jednak zbyt powierzchowne i pewne jest, że Jezus nie zadawał go $\mathrm{z}$ tego powodu. Jezus bowiem żąda od swoich uczniów odpowiedzi szczerej i pełnej, która miała rzucić światło na istotę tajemnicy relacji ich - uczniów do Jezusa - ich Mistrza i Nauczyciela ${ }^{42}$. Tak więc Jezus chce sprowokować swych uczniów, by „zajrzeli w głąb siebie" i odkryli tam to, kim dla każdego z nich jest Jezus ${ }^{43}$. Takie pytanie spowodować musiało u uczniów głębokie milczenie, „podobne do milczenia dziewczyny zapytanej o zgodę na małżeństwo z młodzieńcem, którego w skrytości serca szczerze kocha"44.

Pytanie postawione przez Jezusa swym uczniom, według J. Galot, nie ma charakteru wyłącznie spekulatywnego. Dlatego odpowiedź na nie nie może opierać się tylko na konfrontacji rozumu ludzkiego z prawdą objawioną, lecz powinna opierać się na spotkaniu osoby ludzkiej z tą drugą Osobą, która w pierwszej kolejności pyta uczniów o to, kim jest dla nich ${ }^{45}$. Tak więc pytanie to staje przed każdym człowiekiem, który wchodzi w kontakt z Jezusem i wymaga od niego osobistego wyznania ${ }^{46}$. Ewangelie przekazują odpowiedź Piotra na trzy różne sposoby: „Ty jesteś Mesjasz (gr. Christos)” (Mk 8,29), „Za Mesjasza Bożego” (Łk 9,20), „Ty jesteś Mesjasz, Syn Boga żywego” (Mt 16,16). Z tych sformułowań

\footnotetext{
${ }^{40}$ Por. J. Galot, Chi sei Tu, s. 12.

${ }^{41}$ Por. tamże, s. 17-18.

${ }^{42}$ Por. tamże, s. $14-16$.

${ }^{43}$ Por. R. Bartnicki, Wyznanie Piotra, s. 207.

${ }^{44}$ G. Ricciotti, Życie Jezusa Chrystusa, s. 419.

${ }^{45}$ Por. J. Galot, Chi sei Tu, s. 12-14.

${ }^{46}$ Por. Mt 16,13; Mk 8,27; Łk 9,18; także: J. Galot, Chi sei Tu, s. 14-15; S. Krakiewicz, Kim jestem dla was?, „Chrześcijanin” 3 (1966), s. 3.
} 
wynika, że Szymon Piotr, odpowiadając w imieniu wszystkich Apostołów, wyznaje, że Jezus jest Mesjaszem, a tym samym potwierdza Jego mesjańskie posłannictwo ${ }^{47}$.

Wydaje się, że najbardziej pierwotna formuła i najbardziej oryginalne twierdzenie wypowiedziane przez Piotra zachowało się w Ewangelii Markowej. Treść wyznania Piotrowego, którą zamieścił św. Marek w swej Ewangelii, została ujęta w różny sposób przez pozostałych synoptyków, którzy korzystali ze źródeł zbieranych w okresie popaschalnym, jednak zawsze opartych na nauczaniu pochodzącym od pierwszych świadków Jezusa. Zatem wyznanie Piotra zawiera w sobie te treści, jakie wówczas mogły być znane światłemu Izraelicie, który z uwagą obserwował przez dłuższy czas znaki dokonywane przez Mistrza z Nazaretu ${ }^{48}$. Ewangelista Mateusz do słów Piotrowych dołączył więc jeszcze wyznanie wiary, pochodzące $\mathrm{z}$ okresu popaschalnego, w synostwo Boże Jezusa, gdy po wydarzeniach Pentakostalnych uczniowie poznali pełniej osobę Jezusa ${ }^{49}$.

47 „Boismard w Synopse des quatre Evangiles en français (Paris 1972, II, 243) uważa, że na pytanie: 'Za kogo mnie uważacie?' - z ust Piotra miała paść odpowiedź taka, jaką zapisał autor czwartej Ewangelii (J 6,69): 'Tyś jest świętym Boga = sy ei ho hagios tou theou'. Formuła ta nie była ściśle chrystologiczna, jest natomiast poświadczona w Mk 1,24 (ho hagios tou theou) i w Łk 4,34 jako wyznanie ducha nieczystego. Warto tu odnotować, że według Boismarda w tej sekcji Ewangelia Janowa ma być zależna od tzw. dokumentu B, od którego głównie miałby się wywodzić Mk pośredni. Boismard zwraca uwagę na to, że Jan zaczerpnął tę formułę właśnie z owego dokumentu. Dowodzi on swoje zdanie następująco: gdyby autor Ewangelii Janowej znalazł w swoim dokumencie formułę znaną z obecnego Mk, nie usiłowałby jej zmieniać na taką, która w swej treści była mniej znacząca. Natomiast Mk zmienił formułę dokumentu B na tę, którą obecnie odczytujemy: 'Tyś jest Chrystus', gdyż była ona bardziej zrozumiała dla czytelników greckich jego Ewangelii. Natomiast ostatni redaktor Ewangelii Łukaszowej dokonał kombinacji formuły poświadczonej przez Jana, którą winien czytać w Proto- Łk, połaczonym z dokumentu B i z Mk (już pośredniego). Stąd jego wyrażenie: Mesjasz Boży. Wreszcie ostatni redaktor Ewangelii Mt porzucił formułę, jaką znalazł w Mt pośrednim (prawdopodobnie tę, którą przekazuje J w 6,69), a którą znaleźć mógł nie tylko w dokumencie B, ale też w A. Aby zaadoptować dla swego dzieła formułę Marka pośredniego, Mateusz pośredni zamieścił w wyznaniu: 'Tyś jest Chrystus. Syn Boga żywego". J. Łach, Formuła: Tyś jest Chrystus, s. 43-44; por. także R. Bartnicki, Wyznanie Piotra, s. 207n.

${ }^{48}$ Por. J. Łach, Formuła: Tyś jest Chrystus, s. 46.

49 Por. R. Bartnicki, Wyznanie Piotra, s. 208; także J. Galot, Chi sei Tu, s. 17-19. 
Dużą trudność sprawia egzegetom ustalenie pełnego sensu Piotrowego wyrażenia: „Syn Boga żywego”, które mieści się w Mt 16,16. Dyskusyjne jest bowiem, czy tytuł ten oznacza bóstwo Jezusa, czy tylko Jego godność mesjańską. Jednakże te perykopy, w których dostrzega się redakcję Mateusza, tytuł „Syn Boży”, podobnie jak w kerygmacie apostolskim, oznacza bóstwo Jezusa. Do tekstów tych zalicza się: Ewangelię dzieciństwa, w której za pomocą cytatów refleksyjnych stara się wykazać synostwo Boże Jezusa; wyznanie Piotra; pytanie arcykapłana podczas sądu nad Jezusem oraz wyznanie uczniów: „Prawdziwie jesteś Synem Bożym” (Mt 14,33), widzących Jezusa, który chodzi po Jeziorze Galilejskim ${ }^{50}$. $\mathrm{Na}$ uwagę w tym względzie zasługuje zdanie R. Bartnickiego: „Nie do utrzymania jest już pogląd, że słowa Piotra zawierały wyznanie wiary w godność boską Jezusa. Mało przekonywająca jest opinia (np. O. Cullmanna), że słowa 'Syn Boga żywego' są wyrazem późniejszej parafrazy liturgicznej i parenetycznej, która raczej zubożyła wymowę tytułu mesjańskiego, gdyż określenie „Syn Boga” w tekstach biblijnych odnoszono zarówno do jednostek (np. 2 Sm 7,14; Ps 2,7; 89,27n), jak i do całego ludu Bożego (np. Wj 4,22; Pwt 14,1; 32,6.18; Jr 31,9) i wskazywało ono na specjalną łączność z Bogiem, ale nie miało znaczenia mesjańskiego. Nie wydaje się też słuszne mniemanie (np. P. Bonnarda), że tytuły „Syn Boga” i "Syn Boga żywego" są synonimami i mówią o zbawczym posłannictwie eschatologicznym Jezusa, a tytuł „Syn Boga żywego” jest nawiązaniem do starotestamentowego zwrotu „Bóg żywy” (por. Pwt 5,23; Iz 37,4; Jr 5,2 itd.) i określa Jezusa jako reprezentanta Boga, który interweniuje w dzieje ludzkości, by ją sądzić i zbawić” 51 .

Po części sens tytułu „Syn Boga żywego” znajduje swoje wyjaśnienie w synowskim postępowaniu Jezusa wobec Boga. Jezus jako Syn odróżnia się od innych Żydów i stawia się w jedynej i niepowtarzalnej relacji do Boga Ojca. Świadomość Jego Bożego synostwa Mateusz najdobitniej wyraził w 11,27: Jezus stawia się tu nie tylko obok Ojca, lecz nawet rości sobie prawo do wiedzy Ojca. Chrystus jako Syn „zna” (Mt 11,27) Ojca. A „znać” w języku biblijnym nie oznacza tylko pozna-

${ }^{50}$ Por. J. Kudasiewicz, Ewangelie synoptyczne. Ewangelia według św. Mateusza, w: Wstęp do Nowego Testamentu, s. 191.

${ }^{51}$ R. Bartnicki, Wyznanie Piotra, s. 207-208. 
nia intelektualnego i abstrakcyjnego, ale poznanie witalne, które ujawnia też doświadczenie miłości i wspólnoty osób. Dlatego też synostwo Boże Jezusa jest synostwem wyłącznym i szczególnym ${ }^{52}$. Ten szczególny aspekt synostwa widoczny jest w sposobie Jezusowego zwracania się do Boga, używając słowa „Abba” (Mk 14,36), które wskazuje na bardzo intymny kontakt z Bogiem ${ }^{53}$.

Powyższa odpowiedź Piotrowa: „Tyś jest Chrystus, Syn Boga żywego" znajduje swe potwierdzenie w uroczystym pytaniu skierowanym do Jezusa przez najwyższego arcykapłana podczas procesu: „Przysięgam Cię na Boga żywego, powiedz, czy Ty jesteś Chrystus, Syn Boga żywego?” (Mt 26,63). Z oskarżenia tego wynika, że Jezus przez swą naukę oraz swe czyny pretendował do bycia nie tylko Mesjaszem, lecz także Synem Bożym ${ }^{54}$. W związku z tym Piotr, udzielając Jezusowi odpowiedzi, w przenikaniu tajemnic Chrystusa posuwa się o wiele dalej niż ktokolwiek inny, bowiem odkrywa to, być może nieświadomie, co Jezus objawi w sposób uroczysty dopiero przed Kajfaszem - Jego Synostwo Boże ${ }^{55}$.

Dla Piotra bowiem Jezus rzeczywiście był Panem, Bogiem i Zbawicielem, Synem Bożym. Jednakże nie mogło być ono w całości skutkiem osobistego poznania, ponieważ ludzka percepcja nie sięga tak daleko. Nie dotarł tak daleko także i Piotr, chociaż był uczniem Jezusa i codziennie ze swym Mistrzem przebywał. Dlatego Jezus powiedział do niego: „Błogosławiony jesteś Szymonie, synu Jony, bo tego ciało i krew nie objawiły tobie, ale Ojciec mój, który jest w Niebie" (Mt 11,27) ${ }^{56}$. Z tej wypowiedzi Jezusowej wynika, że rezultatem objawienia Bożego jest to, iż człowiek grzeszny, który jest w duchowej ciemności i ma czasami nawet błędne, nieprawdziwe i niepełne wyobrażenie o Jezusie Chrystusie, o sprawach zbawienia i życia wiecznego, oświecony zostaje Bożym światłem tak,

${ }^{52}$ Por. J. Kudasiewicz, Ewangelie synoptyczne. Ewangelia według św. Mateusza, s. $191 \mathrm{n}$.

${ }^{53}$ Por. J. Galot, Chi sei Tu, s. 19-20.

${ }_{54}$ Por. tamże.

${ }_{55}$ Por. tamże, s. 20-21; także tenże, Serce Ojca, s. 266.

56 „Jest to ciekawe świadectwo ukazujące, w jaki sposób, według pierwotnego Kościoła, rozpoznana została mesjańska godność Jezusa”. R. Bartnicki, Wyznanie Piotra, s. 208. 
że przychodzi do poznania pewnej prawdy Bożej. Przykładem tego jest Szymon Piotr ${ }^{57}$.

Jezus akceptuje mesjańską deklarację Piotra, lecz jednocześnie jeszcze ją uściśla w Mk 8,31, precyzując, że jest Synem Człowieczym, który będzie wiele cierpiał ${ }^{58}$. Cierpienie Syna Bożego stanie się dla uczniów trudnym, a zarazem ważnym i istotnym probierzem wiary. Bowiem rzeczywistość cierpienia jest nieodłączna ze związaniem się z Chrystusem ${ }^{59}$, na wzór odrzucenia ich Mistrza przez wszystkie świętości Izraela ${ }^{60}$. Wtedy to uczniowie Jego doznają szoku, łamie się ich niedoskonała wiara, a na jej gruzach powstaje nowa, doskonała, z poranka wielkanocnego ${ }^{61}$.

Uczniowie byli zakłopotani, gdy przyszło im odkryć właściwy i pełny sens Piotrowej odpowiedzi ${ }^{62}$. Sam Piotr pozostawił „w spadku” swemu gronu słuchaczy, a wśród nich także późniejszemu Ewangeliście - Markowi, wyznanie, iż nie był on zdolny, chociaż powinien, obserwując liczne, cudowne dzieła Jezusa, lepiej i pełniej poznać treść tytułu „Mesjasz”, który zawierał nie tylko te treści, jakimi przesiąknięci byli oczekujący na Niego Żydzi, lecz także i te, za które Go sądzili na śmierć, wydając władzy rzymskiej. Dowiadujemy się bowiem z opisu procesu Jezusa, że już wtedy określano Go - Jezusem, Synem Błogosławionego i Synem Człowieczym, który jest Chrystusem ${ }^{63}$. Piotr, który po Zmartwychwstaniu Jezusa w dniu Pięćdziesiątnicy świadomie stanął na czele swych braci Apostołów, bardzo ubolewał, że nie zrozumiał pełnej treści powyższego tytułu. Wspomniał wtedy fakt, że wyznał on wprawdzie w Jezusie Mesjasza, ale w tym wyznaniu nie zawarł całej o Nim prawdy, tj. tego, że jest

${ }^{57}$ Por. J. Galot, Chi sei Tu, s. 20; także: S. Krakiewicz, Kim jestem, s. 3; R. Bartnicki, Wyznanie Piotra, s. 208.

${ }^{58}$ Jest to typowe stwierdzenie Jezusa, ustosunkowujące się do popularnych wyobrażeń mesjańskich. Podobnie w Mk 14,61 oraz J 18,37 Jezus akceptuje tytuł użyty przez swego rozmówcę, ale natychmiast dokonuje korekty jego znaczenia. Por. R. Bartnicki, Wyznanie Piotra, s. 207.

${ }_{59}$ Por. J 15,20; Łk 11,49; Mt 5,11; 13,21.

${ }^{60}$ Por. Mt 27,15-26; Mk 15,6-15; Łk 23,17-25; J 19,15n.

${ }_{61}$ Por. E. Szymanek, Za kogo mnie, s. 232.

${ }^{62}$ Por. J. Galot, Chi sei Tu, s. 20-21.

${ }^{63}$ Por. J. Łach, Formuła: Tyś jest Chrystus, s. 46-47. 
On Synem Bożym i Synem Człowiekiem. Prawdę tę poznał on później i za nią poniósł śmierć męczeńską w Rzymie ${ }^{64}$.

Chociaż wyznanie wiary przez Piotra Apostoła pod Cezareą Filipową było jeszcze niedoskonałe, to jednak posiada kategorię prawdy. Wyrażało ono może niepełną, ale jednak prawdę o Jezusie. Bowiem formuły ludzkie, takie jak np. w Ewangeliach, mimo że nie wyrażają całej prawdy o Nim, to jednak są właściwe do określania realnego obrazu osoby Jezusa $^{65}$.

Innym elementem charakterystycznym dla „wyznania Piotrowego” jest jego jedność i zarazem zgodność na nie wszystkich pozostałych Apostołów. I, gdy wśród ludzi panują opinie różne i niezgodne, to pierwotną grupę chrześcijan charakteryzuje jedność w wyznawaniu wiary. Taki stan rzeczy wynika z różnicy między „obcymi”, dla których cała nauka Chrystusowa opiera się na przypowieściach, oraz grupą „Dwunastu”, której została przekazana „tajemnica Królestwa Bożego”66.

Właśnie omawiana sytuacja ma też swą egzemplifikację w przyszłości. W historii bowiem wystąpią zawsze „wśród tych z zewnątrz" różne opinie o Jezusie, tworząc „nowe” chrystologie. Nawet ostatnio mówi się o różnych chrystologiach w Nowym Testamencie ${ }^{67}$. Wśród tych wszystkich chrystologii istnieje różnica $\mathrm{w}$ sposobie rozważania osoby i dzieła Jezusa Chrystusa, gdyż każdy z autorów ma swoje własne podejście do widzenia Jezusa i opisywania Jego fenomenu. Mimo to pluralizm ten wyklucza wszelką niezgodność w zakresie istoty wiary. Różne bowiem chrystologie zgadzają się w jedynej chrystologii, która, kontynu-

${ }^{64}$ Por. J. Galot, Chi sei Tu, s. 20-21; także J. Łach, Formuła: Tyś jest Chrystus, s. 47 .

${ }^{65}$ Por. J. Galot, Chi sei Tu, s. 20-21.

${ }^{66}$ Por. Mk 4, 11; także: J. Galot, Chi sei Tu, s. 23; E. Szymanek, Wykład Pisma Świętego Nowego Testamentu, Poznań 1990, s. 109.

${ }^{67}$ B. Mondin w „Le cristologie moderne” podaje następujące kwalifikacje współczesnych chrystologii: 1/ metafizyczne: P. Parente, R. Guardini, M. D. Chenu, J. Galot, Ch. Duquoc, G. Florovsky; 2/ egzystencjalne: K. Barth, G. Ebeling, R. Bultmann, P. Tillich, K. Rahner; 3/ historyczne: O. Cullmann, W. Pannenberg, W. Marxsen, W. Kasper; 4/ sekularystyczne: D. Bonhoeffer, J. Robinson, P. Van Buren, P. Schoonenberg, P. Teilhard de Chardin, H. Küng, E. Schillebeeckx; 5/ eschatologiczne: J. Moltmann, K. Braaten; 6/ polityczne: J. B. Metz, G. Gutierrez, L. Boff, F. Belo. Inny podział: A. Nossol, Per Christum, s. 6-23. 
ując chrystologię Kościoła pierwotnego, wyznaje jego wiarę w Chrystusa, Syna Bożego ${ }^{68}$.

Jak nie można zapomnieć o dynamizmie wiary, która zawsze przekracza granice ludzkich formuł, tak nie można zaprzeczyć obiektywnej wartości twierdzeń w chrystologii. Twierdzenia te winny jednak nieustannie służyć pogłębieniu sensu „wyznania Piotrowego”: „Ty jesteś Chrystus, Syn Boga żywego"69. Dlatego też chrystologia musi podjąć się poszukiwania najlepszego sposobu na wyrażenie Boga, który objawił się w sposób ostateczny w Jezusie Chrystusie. I wszystkie te wypowiedzi muszą mieścić się w pewnych stałych elementach przekazywanych przez tradycję chrześcijańską ${ }^{70}$.

\section{ZAKOŃCZENIE}

„Kim On jest?” - takie pytanie stawiali sobie ludzie, obserwując czyny i słowa Jezusa podczas Jego życia ziemskiego. Pytanie to przez wszystkie czasy aż do tej pory nie straciło nic ze swej aktualności. Staje ono przed ludźmi wszystkich czasów i miejsc, domagając się „starych i nowych" odpowiedzi ${ }^{71}$, które będą adekwatne do ducha czasów stawiających to pytanie. Pewne jest jednak, że muszą one w każdej epoce pozostać niezmienne w swej istocie, w swym rdzeniu ontycznym. Muszą być zakotwiczone w dogmacie, który jest ich drogą o ściśle określonym kierunku, rozciągającym się na linii odpowiedzi Piotrowej w pierwszym dialogu chrystologicznym ${ }^{72}$.

Taką właśnie drogę dynamicznej wiary w osobę i dzieło Jezusa Chrystusa obrał J. Galot. Jego wiara chrystologiczna wyrasta z dialogu rozpoczętego przez Jezusa $\mathrm{z}$ uczniami i jest kontynuowana w permanentnym dialogu człowieka wierzącego i szukającego odpowiedzi na pytanie: Kim jest Jezus?

\footnotetext{
${ }^{68}$ Por. J. Galot, Chi sei Tu, s. 23.

${ }^{69}$ Por. tamże.

${ }^{70}$ Por. W. E. May, Chrystus w myśli, s. 10.

71 Por. Mt 13,52.

${ }^{72}$ Por. J. Galot, Chi sei Tu, s. 23; także J. Królikowski, Mysteria vitae Christi,
} s. $21-22$. 


\section{BIBLIOGRAFIA}

Bartnicki R., Wyznanie Piotra pod Cezarea Filipowa i obietnica prymatu, „Homo Dei” 3 (1980), s. 205-211.

Duquoc Ch., Jezus Chrystus. Zarys chrystologii, tłum. D. Szumska, Warszawa 1976.

Galot J., Chi sei Tu, o Cristo, Firenze 1977.

Galot J., Serce Ojca, [tł. S. M. G.], Warszawa 1962.

Granat W., Dogmatyka katolicka, Lublin 1959.

Gryglewicz F., Za kogo mnie uważacie? Chrystus w oczach swoich współczesnych, Poznań-Warszawa-Lublin 1966.

Jan Paweł II, bulla „Incarnationis mysterium”, Poznań 1998.

Katechizm Kościoła Katolickiego, Poznań 1994.

Krakiewicz S., Kim jestem dla was?, „Chrześcijanin” 3 (1966), s. 3-12.

Łydka W., Potrzeba $i$ drogi integracji $w$ chrystologii, „Studia Theologiae Varsoviensia” 15 (1977) 1, s. 68-77.

Mondin B., Le cristologie moderne, Alba 1976.

Nossol A., Teologia bliższa życiu. Wpływ teologii na egzystencję chrześcijańską, Opole 1984.

Poniatowski Z., Chrystologia - kierunki, problemy, aporie, „Literatura na świecie” 12 (1974), s. 92-101.

Ricciotti G., Życie Jezusa Chrystusa, tłum. J. Skowroński, Warszawa 1954.

Szymanek E., Wykład Pisma Świętego Nowego Testamentu, Poznań 1990.

Wielka Encyklopedia Powszechna PWN, Warszawa 1965. 